\title{
Neuropeptide $Y_{1}$ Receptors Inhibit $N$-Type Calcium Currents and Reduce Transient Calcium Increases in Rat Dentate Granule Cells
}

\author{
A. Rory McQuiston, ${ }^{1}$ Jeffrey J. Petrozzino,? John A. Connor, ${ }^{2}$ and William F. Colmers ${ }^{1}$ \\ ${ }^{1}$ Department of Pharmacology, University of Alberta, Edmonton, Alberta, Canada T6G 2H7, and ${ }^{2}$ Roche Institute of \\ Molecular Biology, Roche Research Center, Nutley, New Jersey 07110-1199
}

Neuropeptide Y (NPY) is far more abundant in the dentate gyrus than elsewhere in the hippocampal formation, but it does not alter the synaptic excitation of dentate granule cells (DGCs) as it does for pyramidal cells in areas CA1 and CA3. NPY inhibited depolarization-induced increases in intracellular $\mathrm{Ca}^{2+}$ concentrations $\left(\left[\mathrm{Ca}^{2+}\right]_{i}\right)$ in DGCs in hippocampal slices, without altering the resting $\left[\mathrm{Ca}^{2+}\right]_{i}$. NPY inhibited $\mathrm{Ca}^{2+}$ currents $\left(I_{\mathrm{Ca}}\right)$ via a $\mathrm{Y}_{1}$ receptor in $84 \%$ of acutely isolated DGCs and via a $Y_{2}$ receptor in $31 \%$ of the NPY-responsive cells tested. $I_{\text {Ca }}$ inhibition was completely occluded by $\omega$-conotoxin-GVIA but not by nimodipine. The inhibition of $I_{\mathrm{Ca}}$ was accompanied by a change in the time course of $I_{\mathrm{Ca}}$ activation in only $27 \%$ of NPY-responsive cells. Only $23 \%$ of DGCs responded to NPY when $\mathrm{Ba}^{2+}$ was substituted for extracellular $\mathrm{Ca}^{2+}$ and when $\left[\mathrm{Ca}^{2+}\right]_{i}$ was strongly buffered.

Therefore, NPY inhibits an N-type $I_{\mathrm{Ca}}$ in DGCs, mainly via $\mathrm{Y}_{1}$ receptors. Furthermore, it seems that more than one mechanism, one of which may be sensitive to $\left[\mathrm{Ca}^{2+}\right]_{i}$, may couple NPY receptors to the $\mathrm{Ca}^{2+}$ channels in DGCs. Because the release of dynorphin from DGCs depends in part on N-type currents, NPY receptors are poised to regulate the release of opioid peptides from DGC somata and dendrites.

Key words: neuropeptide $Y ; Y_{1}$ receptor; voltage-dependent calcium current; dentate gyrus granule cell; acutely dissociated neurons; intracellular calcium imaging
Neuropeptide Y (NPY) and its receptors are found in large quantitics in widely distributed regions of the vertebrate peripheral nervous system (PNS) and CNS (Dumont et al., 1990, 1992, 1993; Hendry, 1993; Sundler et al., 1993; Wahlestedt and Reis, 1993). NPY has a substantial number of documented actions on physiology and/or behavior in the mammalian PNS and CNS (Colmers and Bleakman, 1994; Wahlestedt and Reis, 1993). The cellular mechanisms of the actions of NPY, however, especially in the CNS, are not well understood.

In the mammalian CNS, very high concentrations of NPY and its receptors are found in the hippocampus (Dumont et al., 1992, 1993; Hendry, 1993). NPY binding is found in high density in the strata radiatum and oriens of hippocampal areas CA1 and CA3, where NPY potently and selectively inhibits (glutamatergic) synaptic excitation of CA1 (Colmers et al., 1987, 1988; Haas et al., 1987) and CA3 pyramidal neurons (McQuiston and Colmers, 1992; Klapstein and Colmers, 1993) via a receptor of the $\mathrm{Y}_{2}$ subtype (Colmers and Bleakman, 1994). In the hippocampal formation of the rat, NPY is most concentrated in the dentate gyrus (Hendry, 1993), and substantial specific binding for NPY is present in the molecular layer of the dentate gyrus (Dumont et al., 1990, 1993), where afferent inputs from the entorhinal cortex form synapses with the dendrites of dentate

\footnotetext{
Received Sept. 5, 1995; revised Dec. 4, 1995; accepted Dec. 12, 1995.

This research was supported by the Medical Research Council of Canada. A.R.M. was supported by a Studentship for the Alberta Heritage Foundation for Medical Research (AHFMR). W.F.C. is a Senior Scholar of the AHFMR. We thank Miles, Inc., for their gift of nimodipine and Ciba-Geigy for their gift of Lioresal (bacloten). We thank Mr. Douglas Fraser for his advice on the dissociation technique, Drs. Aaron Fox, Fred Tse, and Dan Johnston for their comments, and Dr. Penny Brooks for lively discussions.

Correspondence should be addressed to Dr. William F. Colmers, Department of Pharmacology, University of Alberta, 9-36 MSB, Edmonton, Alberta, Canada T6G 2 H7.

Dr. McQuiston's present address: Department of Molecular and Cellular Physiology, Stanford University School of Medicine, Stanford, CA 94305.

Copyright (C) 1996 Society for Neuroscience $0270-6474 / 96 / 161422-\bullet \$ 05.00 / 0$
}

granule cells (DGCs) (Laatch and Cowan, 1967; Hjorth-Simonsen and Jeune, 1972). Receptor binding studies indicate that the NPY receptor in the dentate gyrus is mostly $\mathrm{Y}_{1}$, in contrast to the predominantly $\mathrm{Y}_{2}$ receptors of areas CA1 and CA3 (Dumont et al., 1990, 1992, 1993; Aicher et al., 1991; Wahlestedt and Reis, 1993). Despite this, however, no effect of NPY has been observed on synaptic inputs to DGC's or on the passive electrical properties of the DGCs (Klapstein and Colmers, 1993), with the exception of a single report of a direct cxcitatory cffect (Brooks et al., 1987). Therefore, a function for NPY and its receptors in the dentate gyrus remains elusive.

NPY inhibits N-type voltage-dependent calcium channels (VD$\mathrm{CCs}$ ) of vertebrate PNS neurons such as sympathetic $\mathrm{C}$ cells, rat myenteric plexus neurons, and rat sensory neurons (for review, see Bleakman et al., 1993; Colmers and Bleakman, 1994). NPY also inhibits both N- and L-type VDCCs of frog melanotrophs (Valentijn et al., 1994). In most cases, NPY inhibits the N-type VDCCs by activating a $Y_{2}$ receptor. By contrast, in some nodose ganglion neurons of the rat, NPY potentiates the same N-type VDCC via a $Y_{1}$ receptor that it inhibits via a $Y_{2}$ receptor (Wiley et al., 1993). NPY also augments VDCCs in rat vascular smooth muscle (Xiong et al., 1993). Furthermore, NPY often is coupled to intracellular calcium mobilization in neurons and other cell types (Michel, 1991; Dumont et al., 1992; Wahlestedt and Reis, 1993).

Hcrc we investigated the possibility that NPY acts either to alter intracellular calcium homeostasis [possibly by elevating intracellular $\mathrm{Ca}^{2+}$ concentrations $\left.\left(\left[\mathrm{Ca}^{2+}\right]_{\mathrm{i}}\right)\right]$ or to modulate VDCCs of rat DGCs. We have found that NPY inhibits N-type VDCCs and reduces activity-dependent $\mathrm{Ca}^{2+}$ increases in rat DGCs, predominantly by activating a $\mathrm{Y}_{1}$ receptor.

\section{MATERIALS AND METHODS}

Calcium imaging experiments. Experiments were performed on DGCs in $450 \mu \mathrm{m}$ transverse slices of 21 - to 30 -d-old male Sprague-Dawley rats. 
Rats were anesthetized with halothane and decapilated. Braiss were removed rapidly and placed in ice-cold saline $\left(4^{\circ} \mathrm{C}\right)$. The hippocampus was then dissected from the brain and cut on a Vibratome. Slices were placed on a polypropylene mesh, submerged, and continuously perfused with saline $\left(23^{\circ} \mathrm{C}\right.$ ) containing (in $\left.\mathrm{mm}\right): 124 \mathrm{NaCl}, 2 \mathrm{KCl}, 1.3 \mathrm{MgSO}_{4}, 1.25$ $\mathrm{KH}_{2} \mathrm{PO}_{4}, 18 \mathrm{NaHCO}_{3}, 2.5 \mathrm{CaCl}_{2}$, and 10 glucose equilibrated with $95 \%$ $\mathrm{O}_{2} / 5 \% \mathrm{CO}_{2}, \mathrm{pH} 7.4$. Recordings from DGCs were obtained in the whole-cell patch-clamp configuration (Blanton et al., 1989) using patch electrodes (5-9 M $\Omega$ ) filled with $200 \mu \mathrm{M}$ Fura-2 ( $\mathrm{K}^{+}$salt; Molecular Probes, Eugene, OR) dissolved in the intracellular solution consisting of (in mM): $135 \mathrm{~K}$-gluconate, $2 \mathrm{Mg}$-ATP, $0.3 \mathrm{Na}$-GTP, and $10 \mathrm{HEPES}$, pH 7.2. Ncurons wcrc held at $60 \mathrm{mV}$ in the continuous voltage-clamp mode using an Axoclamp 2A amplifier (Axon Instruments, Burlingame, CA), and $500 \mathrm{msec}$ voltage steps to $0 \mathrm{mV}$ were made periodically to stimulate voltage-dependent $\mathrm{Ca}^{2}$ influx.

Imaging experiments were performed from the top surface of the slice using an upright microscope (Zeiss Axioscope) and a $40 \times$ water immersion objective (Zeiss, Thornwood, NY). Digital images were taken with a cooled charge-coupled device camera system (Photometrics, Tucson, AZ) in the frame-transfer mode to acquire image pairs at 360 and $380 \mathrm{~nm}$ excitation wavelengths. $\mathrm{Ca}^{2+}$ levels were calculated from backgroundcorrected images using the ratio method (Grynkiewicz et al., 1985; Tsien, 1989). Calibration of the indicator was carried out under in vitro conditions using general procedures described previously (Connor, 1986). For these measurements, a light path of $20 \mu \mathrm{m}$ was achieved by confining the indicator-saline mixtures in a $20 \times 50 \mu \mathrm{m}^{2}$ capillary (Vitro Dynamics, Rockaway, NJ).

Dissociated cell preparation. Single DGC neurons were isolated from 21- to 30-d-old male Sprague-Dawley rats by a procedure described previously (Kay, 1989; White et al., 1993). Rats were anesthetized with halothane and decapitated. Brains were rapidly removed and placed in ice-cold $\left(4^{\circ} \mathrm{C}\right.$ ) bicarbonate-based artificial CSF (aCSF) saturated with $95 \% \quad \mathrm{O}_{2} / 5 \% \mathrm{CO}_{2}$. The brains were hemisected sagittally with a razor blade and cut on a Vibratome into $500 \mu \mathrm{m}$ transverse slices containing the hippocampal formation. The dentate gyrus was microdissected from these slices and placed in a spinner flask (Belco) containing warm $\left(30^{\circ} \mathrm{C}\right.$ ) dissociation solution saturated with $100 \% \mathrm{O}_{2}$. Slices were allowed to rest for $-15 \mathrm{~min}$ and then treated with $0.2 \mathrm{mg} / \mathrm{ml}$ proteinase $\mathrm{K}$ (Sigma, St. Louis, MO), in the dissociation solution. After $5 \mathrm{~min}$, the solution was exchanged for another solution containing $1 \mathrm{mg} / \mathrm{ml}$ trypsin type $\mathrm{XI}$ (Sigma) and treated for an additional $30 \mathrm{~min}$. After trypsin treatment, the slices were removed, placed in enzyme-free dissociation solution, and allowed to return to room temperature. The slices rested for $1-2 \mathrm{hr}$, and then two slices were triturated in dissociation solution (to which $0.5 \mathrm{mg} / \mathrm{ml}$ bovine serum albumin was added) throngh two fire-polished Pastenr pipettes with tip diameters of $\sim 500$ and $200 \mu \mathrm{m}$, respectively. Cells were placed in a recording chamber and allowed to settle onto poly-L-lysine-coated glass coverslips for $1015 \mathrm{~min}$ before they were washed with a HEPES-bascd aCSF in a recording chamber placed on the stage of an inverted microscope (Nikon Diaphot, Nikon, Mississauga, Ontario, Canada).

Calcium current recording. Currents were recorded from DGC neurons at room temperature $\left(\sim 22^{\circ} \mathrm{C}\right)$ using the whole-cell patch-clamp configuration (Hamill et al., 1981) with an Axopatch 1D amplifier and analyzed with pClamp software (Axon Instruments). Patch electrodes (3-5 M $\Omega$ ) made from borosilicate glass (World Precision Instruments, Sarasota, FL) were not fire-polished or insulated for the measurement of the relatively slow $\mathrm{Ca}^{2+}$ currents we recorded. Whole-cell recording was obtained in the HEPES-buffered aCSF, which was then promptly switched to the calcium current solution. Series resistance and membrane capacitance were electronically compensated by $80-90 \%$ via the amplifier circuitry and were continuously monitored throughout the experiment. Currents were leak-subtracted on-line using a $\mathrm{P} / \mathrm{N}$ protocol and filtered at $1 \mathrm{kHz}$. $I_{\mathrm{Ca}}$ was elicited at $20 \mathrm{sec}$ intervals with $40 \mathrm{msec}$ voltage steps to $+5 \mathrm{mV}$ from a holding potential of $-60 \mathrm{mV}$ or with voltage ramps swept from -80 to $+10 \mathrm{mV}$ over $100 \mathrm{msec}$. Drugs were applied by bath superfusion in the calcium (or barium) current solution.

Significant differences in mean values were tested using the Wilcoxon signed rank test or the Kruskal-Wallis test. Values were considered significantly different for $p<0.05$. Data are presented as mean \pm SEM.

Solutions and materials. The bicarbonate-buffered aCSF used for the dissection consisted of (in mM): $126 \mathrm{NaCl}, 2.5 \mathrm{KCl}, 6 \mathrm{MgCl}_{2}, 2 \mathrm{CaCl}_{2}, 1.25$ $\mathrm{NaH}_{2} \mathrm{PO}_{4}, 26 \mathrm{NaHCO}_{3}, 10$ glucose, and 1 kynurenic acid. The dissociation solution consisted of (in $\mathrm{mM}$ ): $115 \mathrm{NaCl}, 5 \mathrm{KCl}, 20$ PIPES, $1 \mathrm{CaCl}_{2}$, $4 \mathrm{MgCl}_{2}, 25$ glucose, 1 kynurenic acid, and 1 sodium pyruvate. The HEPES-buffered solution used to wash the isolated cells consisted of (in
InM): $135 \mathrm{NaCl}, 2.5 \mathrm{KCl}, 2 \mathrm{MgCl}_{2}, 2 \mathrm{CaCl}_{2}, 20$ HEPES, 20 glucose, and $1 \mathrm{Na}$-pyruvate. The calcium current solution consisted of (in mM): 100 $\mathrm{NaCl}, 2.5 \mathrm{KCl}, 2 \mathrm{MgCl}_{2}, 5 \mathrm{CaCl}_{2}, 20 \mathrm{HEPES}, 3 \mathrm{CsCl}, 30$ tetraethylammonium chloride (TEA-Cl), 5 4-aminopyridine, 10 glucose, and $1 \mathrm{Na}$ pyruvate. All extracellular solutions had a pH of 7.4 and an osmolarity of 315-320 mOsm. The intracellular electrode solution consisted of (in mM): $100 \mathrm{CsCl}, 30 \mathrm{TEA}-\mathrm{Cl}, 10 \mathrm{HEPES}, 4 \mathrm{Mg}$-ATP, $0.3 \mathrm{Na}_{3}$-GTP, 0.1 bis(2-aminophenoxy)ethane- $N, N, N^{\prime}, N^{\prime}$-tetra-acetic acid tetrapotassium salt (BAPTAK $\mathrm{R}_{4}, 14$ ditris phosphocreatine, and $50 \mathrm{UJ} / \mathrm{ml}$ creatine phosphokinase, $\mathrm{pH} 7.2$ (with $\mathrm{CsOH}$ ); the solution had an osmolarity of 280-290 mOsm. For the barium current experiments, the calcium of the extracellular calcium current solution was replaced by equimolar barium, and the BAPTAK $\mathrm{BH}_{4}$ of the intracellular electrode solution was replaced by (BAPTA)-free acid $(20 \mathrm{~mm})$. The $\mathrm{CsCl}$ concentration in the pipette was reduced to compensate for the increased BAPTA concentration.

NPY was obtained from Richelieu Biotechnology (Quebec, Canada); $\left[\mathrm{Leu}^{31}\right.$ Pro $\left.^{34}\right] \mathrm{NPY}, \mathrm{NPY}_{13-36}$, and peptide YY (PYY) were obtained from Bachem (Torrance, CA); $\omega$-conotoxin GVIA ( $\omega$-CTX GVIA) was obtained from Peninsula Laboratories (Belmont, CA); nimodipine was a generous gift from Miles (West Haven, CT); baclofen (Lioresal) was a gift of Ciba-Geigy (Basel, Switzerland) and creatine phosphokinase was obtained from Boehringer Mannheim (Laval, Quebec, Canada). All other compounds were obtained from Sigma.

\section{RESULTS}

\section{NPY inhibits depolarization-induced increases in $\left[\mathrm{Ca}^{2+}\right]_{\mathrm{i}}$ of DGCs}

We first sought to determine whether NPY affected either resting $\left[\mathrm{Ca}^{2+}\right]_{\mathrm{i}}$ or $\mathrm{Ca}^{2+}$ influx in DGCs. For this, we made spatially resolved measurements of $\left[\mathrm{Ca}^{2+}\right]_{i}$ in DGCs loaded with Fura-2 (Grynkewicz et al., 1985) (see Materials and Methods) via a whole-cell patch electrode that also served to measure voltage and injected current. An experiment showing the effects of NPY is illustrated in Figure 1. The resting $\left[\mathrm{Ca}^{2+}\right]$, was not altered by the bath application of $1 \mu \mathrm{M}$ NPY $(n=6)$. To investigate a possible NPY modulation of $\mathrm{Ca}^{2+}$ influx, we depolarized the soma from $-60 \mathrm{mV}$ to $0 \mathrm{mV}$ for $500 \mathrm{msec}$ via the patch pipette. No attempts were made to isolate calcium currents $\left(I_{\mathrm{Ca}}\right)$, and the depolarization produced $\mathrm{Na}^{+}$- and $\mathrm{Ca}^{2+}$-dependent action potentials, which we did not attempt to control. NPY $(1 \mu \mathrm{M})$ significantly decreased the depolarization-induced increase in $\left[\mathrm{Ca}^{2+}\right]_{i}$ compared with that in controls (Fig. 1C,D). Washout of NPY partially reversed the decrease (Fig. $1 E$ ). The data from five experiments are summarized in the histogram (Fig. $1 F)$. NPY $(1 \mu \mathrm{M})$ decreased the depolarization-induced increase in $\left[\mathrm{Ca}^{2+}\right]_{i}$ to $66.6 \pm 2.3 \%$ of the control increase in the soma (Fig. $1 F$ ) and to $55.8 \pm 5.9 \%$ of the control increase in the dendrite (Fig. $1 F)(p<0.05$, Wilcoxon signed rank test). The larger decrease of $\left[\mathrm{Ca}^{2+}\right]_{i}$ in the dendrites compared with the soma was not significantly different $(p>0.05$, Wilcoxon signed rank test).

The most likely means by which NPY could inhibit this depolarization-induced increase in $\left[\mathrm{Ca}^{2+}\right]_{i}$ are by $(1)$ inhibiting VDCCs directly or (2) reducing the excitability of the DGC, such as by increasing $\mathrm{K}^{+}$channel activity or decreasing $\mathrm{Na}^{+}$channel activity and thereby the influx of $\mathrm{Ca}^{2+}$. We first tested the hypothesis that NPY inhibited VDCCs of acutely dissociated neurons.

\section{NPY inhibits voltage-dependent $I_{\mathrm{Ca}}$ s of acutely dissociated DGCs}

We isolated DGCs acutely from rat hippocampal slices and isolated $I_{\mathrm{Ca}}$ (as described in Materials and Methods). DGCs were distinguished from other neuronal types by their small round cell bodies (Mody et al., 1989). Larger DGCs were selected because they usually had a larger $I_{\mathrm{Ca}}$, which also ran down more slowly and recovered more completely from NPY inhibition. DGCs with larger dendrites were also selected because NPY-binding sites are concentrated in 

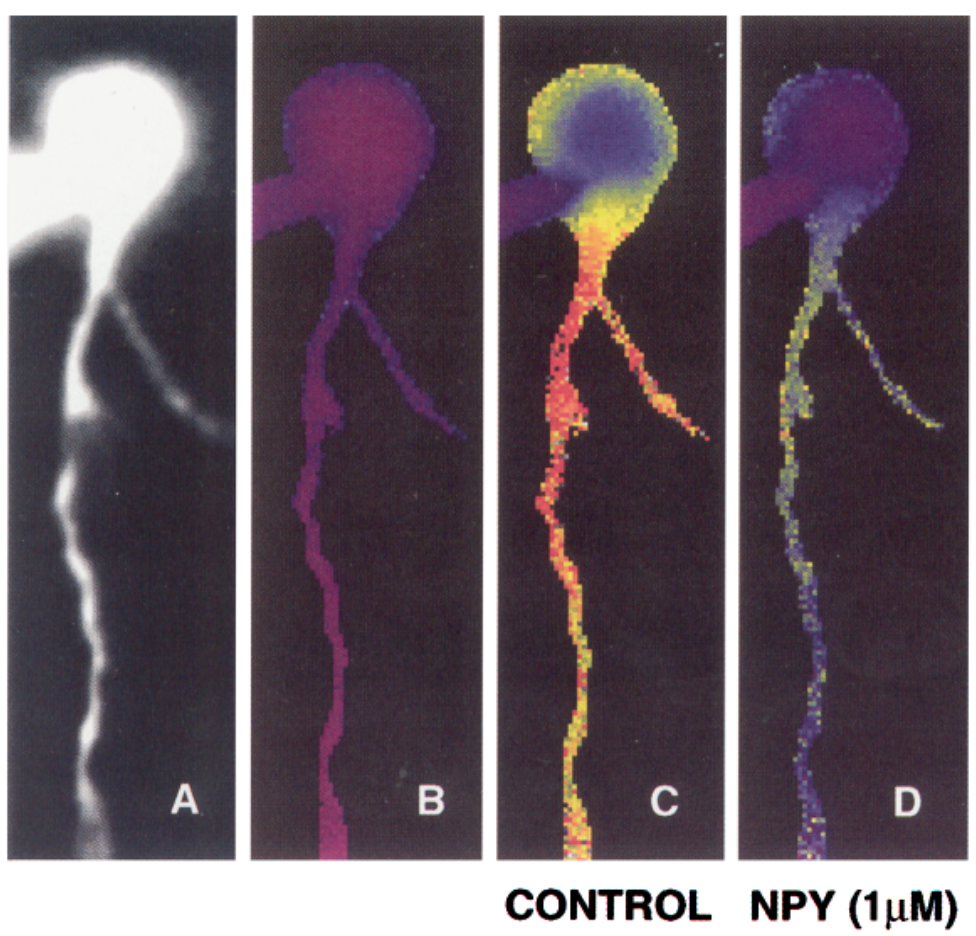

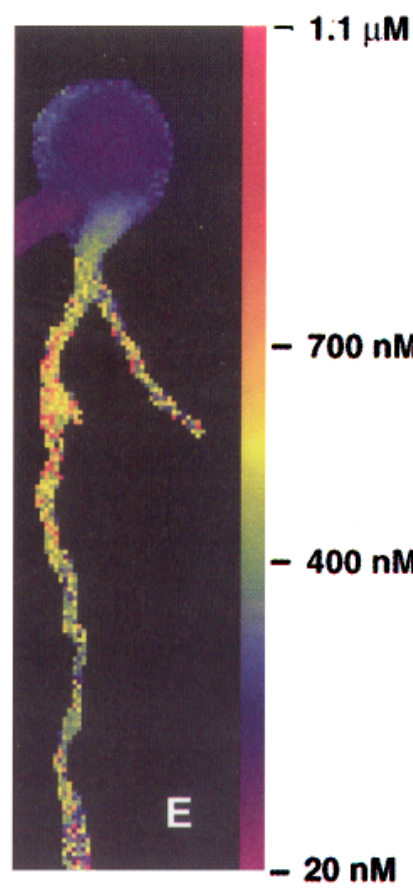

WASH

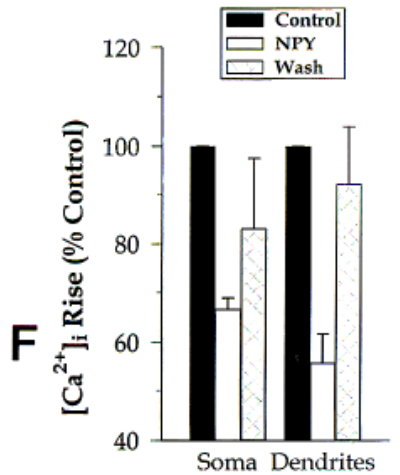

Figure 1. NPY inhibits depolarization-induced increases in $\left[\mathrm{Ca}^{2+}\right]_{\mathrm{i}}$ in DGCs from hippocampal slices. Image of a DGC in a hippocampal slice of the rat. $A$, Fluorescence image with the cell body of the neuron at the top and a bifurcating dendrite underneath. The $\left[\mathrm{Ca}^{2+}\right]_{\mathrm{i}}$ coding for the false color image is on the far right of the figure. The cell was voltage-clamped at $-60 \mathrm{mV}$ and periodically depolarized to $0 \mathrm{mV}$ for $500 \mathrm{msec} . B$, Ratiometric image of the $\left[\mathrm{Ca}^{2+}\right]_{\text {i }}$ of the cell at rest. $C$, The control increase in $\left[\mathrm{Ca}^{2+}\right]_{\mathrm{i}}$ in response to a depolarizing step. $D$, The presence of NPY $(1 \mu \mathrm{M})$ inhibits the increase in $\left[\mathrm{Ca}^{2+}\right]_{i}$ after a depolarizing step. $E$, The increase in $\left[\mathrm{Ca}^{2+}\right]_{\mathrm{i}}$ after a depolarizing step recovers toward control levels after washing out NPY. $F$, Histogram summarizing results of similar experiments $(n=5)$. NPY $(1 \mu \mathrm{M})$ significantly $(p<0.05$, Wilcoxon signed rank test) inhibited depolarization-induced increases in $\left[\mathrm{Ca}^{2+}\right]_{\mathrm{i}}$ of Dendrites in the molecular layer and Soma of DGCs of rat hippocampal slices.

their dendrites (Dumont et al., 1990, 1993; Aicher et al., 1991). Unless otherwise indicated, $I_{\mathrm{Ca}}$ s from DGCs were recorded with 5 $\mathrm{mM} \mathrm{Ca}^{2+}$ in the extracellular solution as the charge carrier and with a pipette solution having low $\mathrm{Ca}^{2+}$ buffering ( $0.1 \mathrm{~mm}$ BAPTA with no added $\mathrm{Ca}^{2+}$; see Materials and Methods). $I_{\mathrm{Ca}}$ s of these DGCs were typically between 200 and 1000 pA in peak amplitude. The maximum peak amplitudes were elicited with voltage steps from -60 $\mathrm{mV}$ to between +5 and $+10 \mathrm{mV}$.

The $I_{\mathrm{Ca}}$ of 42 of 50 acutely dissociated DGCs was inhibited by bath application of $1 \mu \mathrm{M}$ NPY (Fig. 2). Not all cells recovered fully from NPY inhibition, and recovery in many cells took several minutes longer than was required for the complete exchange of the solution in the recording chamber. Some cells showed no apparent recovery within the recording period. Recovery of $I_{\mathrm{C}}$ from NPY inhibition was also obscured by the rapid rate of $I_{\mathrm{Ca}}$ rundown, despite the presence in the pipette of an ATPregenerating solution (see Materials and Methods). Repeated administration of NPY often resulted in a loss of the ability of NPY to inhibit $I_{\mathrm{Ca}}$ (see below).

NPY produced two types of inhibition of $I_{\mathrm{Ca}}$ in DGCs. First, in a great majority of DGCs (33/45 cells), NPY caused a reversible inhibition of $I_{\mathrm{Ca}}$ without an alteration in the time course of $I_{\mathrm{Ca}}$ activation (Fig. $2 A$ ). The second type of $I_{\mathrm{Ca}}$ inhibition by NPY in DGCs was accompanied by a slowing of the activation time course of $I_{\mathrm{Ca}}$ (Fig. $2 B$ ). This second type of inhibition was seen less frequently (12/45 cells); however, it was often more robust and reversible than the other (Figs. $2 B, 3 A, C, D$ ). Peak $I_{\mathrm{Ca}}$ in DGCs that showed a clear change in $I_{\mathrm{Ca}}$ time course after NPY application was inhibited by $38.8 \pm 5.4 \%$ (12/45 DGCs), as opposed to the $22.3 \pm 0.9 \%$ (33/45 DGCs; $p<0.001$, Kruskal-Wallis test) inhibition of peak $I_{\mathrm{Ca}}$ observed in DGCs with no accompanying change in $I_{\mathrm{Ca}}$ activation time course.

\section{NPY inhibits $I_{\text {Ca }}$ of DGCs predominantly by activating a $Y_{1}$ receptor}

At present, NPY seems to have three receptor subtypes, termed $\mathrm{Y}_{1}, \mathrm{Y}_{2}$, and $\mathrm{Y}_{3}$ (Grundemar et al., 1993; Wahlestedt and

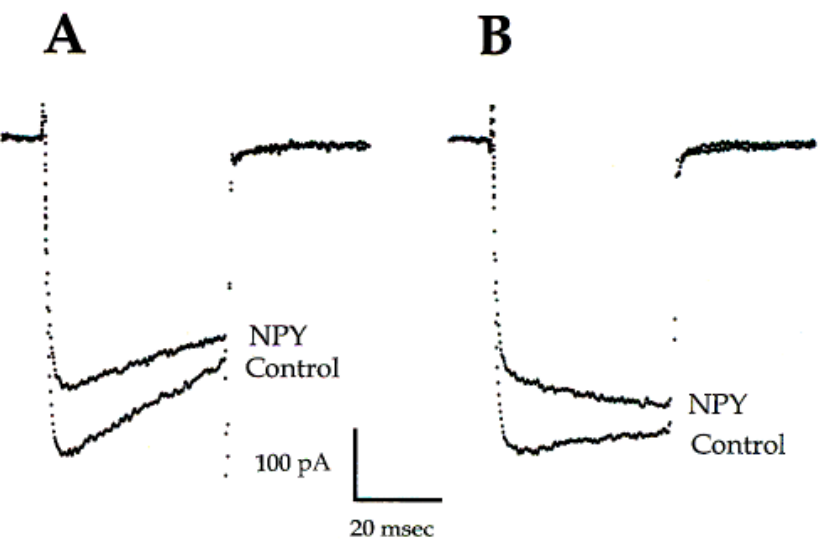

Figure 2. NPY inhibits $I_{\mathrm{Ca}}$ of acutely dissociated DGCs. NPY inhibits the $I_{\mathrm{Ca}}$ of two different DGCs. The $I_{\mathrm{Ca}}$ was elicited by a $40 \mathrm{msec}$ voltage step to $+5 \mathrm{mV}$ from a holding potential of $-60 \mathrm{mV}$. Voltage steps were elicited at $20 \mathrm{sec}$ intervals. $A, N P Y(1 \mu \mathrm{M})$ inhibits the $I_{\mathrm{Ca}}$ of this DGC without markedly altering the time course of activation of the current. $B$, In a different DGC, $N P Y(1 \mu \mathrm{M})$ inhibits $I_{\mathrm{Ca}}$ and slows the time course of activation of the current. 

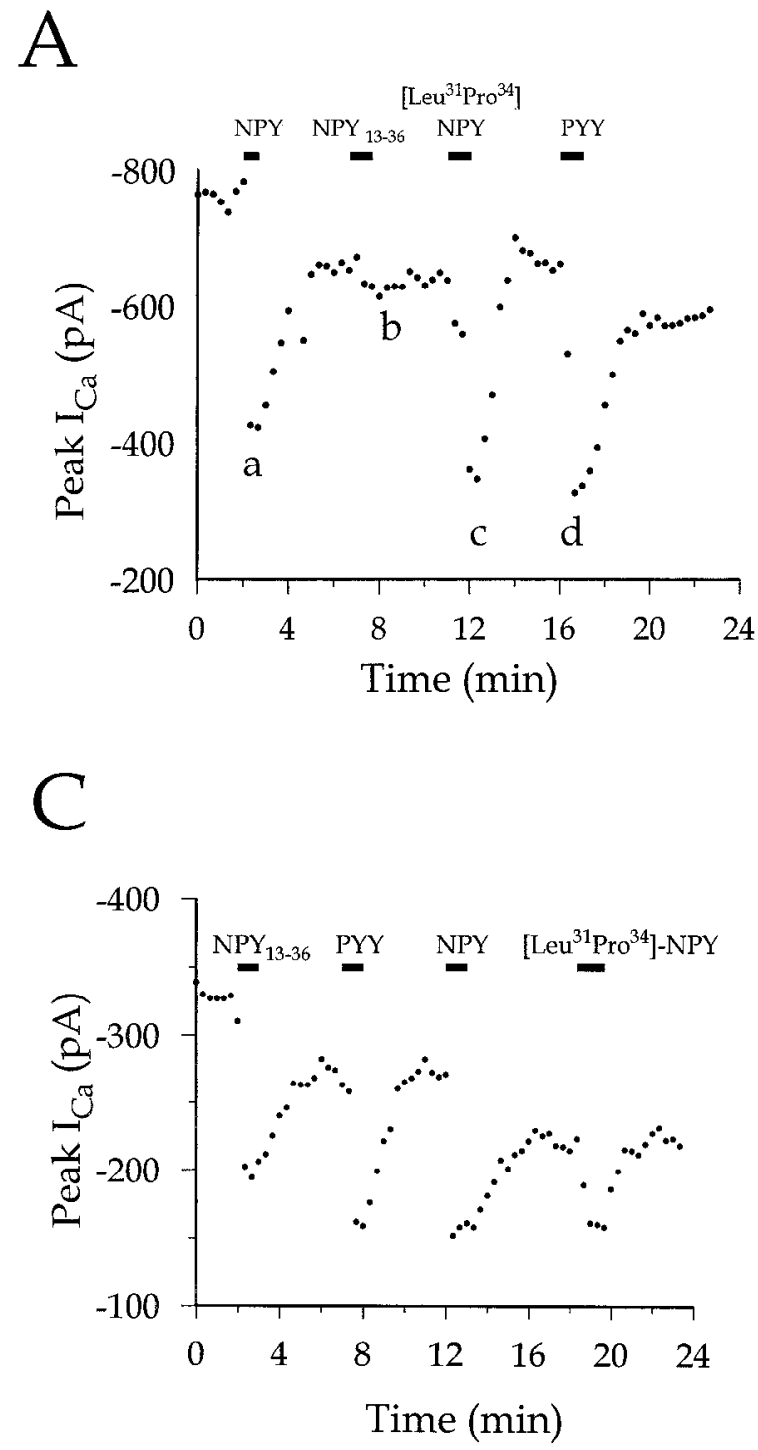

B

a

b
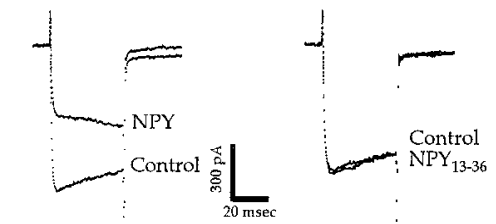

C

d
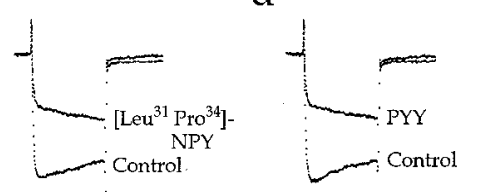

$\mathrm{D}$

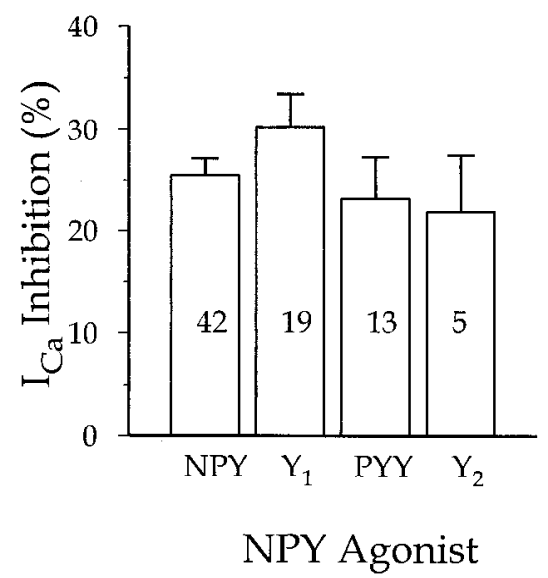

Figure 3. Selective NPY agonists inhibit $I_{\mathrm{Ca}}$ of acutely dissociated DGCs. $A$, Time plot of peak $I_{\mathrm{Ca}}$ from a DGC elicited at $20 \mathrm{sec}$ intervals by a 40 msec voltage step to $+5 \mathrm{mV}$ from a holding potential of $-60 \mathrm{mV}$. The peak current elicited was plotted against the time elapsed from the beginning of the experiment. Drugs were applied during the times indicated by the bars at the top of the plot. NPY, [Leu ${ }^{31}$ Pro $\left.{ }^{34}\right] N P Y$, and PYY inhibited the $I_{\mathrm{Ca}}$ but $N P Y_{13-36}$ did not. All agonists were applied at $1 \mu \mathrm{M} . B$, The $I_{\mathrm{Ca}}$ elicited at the times indicated by the corresponding letters in $A$. Control traces were taken immediately before the respective peptide was applied. Time and current scales are as indicated. $C$, Time plot of $I_{C}$ as in $A . I_{\mathrm{Ca}}$ in this cell was inhibited by all the agonists tested (at $1 \mu \mathrm{M}$ ), including the $\mathrm{Y}_{2}$-selective agonist $N P Y_{13-36} . D$, Mcan \pm SEM perecnt reduction of $I_{\mathrm{Ca}}$ of all cells responding to $1 \mu \mathrm{M}$ of the indicated agonist $\left(Y_{1}=\left[\mathrm{Leu}^{31} \mathrm{Pro}^{31}\right] \mathrm{NPY} ; Y_{2}=\right.$ NPY $13-36$ ). The reductions of $I_{\mathrm{Ca}}$ by the individual agonists are not significantly different $(p>0.30$, KruskalWallis test). All $N P Y$-responsive cells also responded to $\left[\mathrm{Leu}^{31} \mathrm{Pro}^{34}\right] \mathrm{NPY}$ and $P Y Y$ when tested. Only 5 of 16 NPY-responsive cells also responded to $\mathrm{NPY}_{13-36}$.
Reis, 1993). We tested the receptor profile for NPY using $\left[\mathrm{Leu}^{31} \mathrm{Pro}^{34}\right] \mathrm{NPY}\left(\mathrm{Y}_{1^{-}}\right.$and $\mathrm{Y}_{3}$-selective $), \mathrm{NPY}_{13-36}\left(\mathrm{Y}_{2^{-}}\right.$and somewhat $Y_{3}$-selective), and PYY ( $Y_{1}$ - and $Y_{2}$-selective but not $\mathrm{Y}_{3}$-selective), in addition to the nonselective agonist NPY itself.

Figure $3 A$ illustrates the time plot of an experiment in which NPY and the receptor-selective agonists were applied to the same cell. NPY, $\left[\mathrm{Leu}^{31} \mathrm{Pro}^{34}\right] \mathrm{NPY}$, and PYY significantly inhibited the peak $I_{\text {Ca }}$, whereas $\mathrm{NPY}_{13-36}$ did not (Fig. $3 A, B$ ). In this case, because NPY ${ }_{13-36}$ can activate both $Y_{2}$ and $Y_{3}$ receptors (but was inactive here) and PYY was active, NPY must inhibit the $I_{C a}$ of this DGC via a $Y_{1}$ receptor. The current traces show that in this cell, NPY, $\left[\mathrm{Leu}^{31} \mathrm{Pro}^{34}\right] \mathrm{NPY}$, and PYY slow the activation time course of the $I_{\mathrm{Ca}}$ (Fig. $3 B$ ).

Although most DGCs seem to express only $Y_{1}$ receptors (Fig. 3), other DGCs cxpress more than one NPY receptor subtype (Fig. $3 C$ ). In the DGC illustrated in Figure $3 C$, NPY and all three selective agonists inhibited the $I_{\mathrm{Ca}}$. This experiment shows that more than one NPY receptor subtype must be expressed by this DGC, although this protocol did not distinguish whether $Y_{2}$ and/or $\mathrm{Y}_{3}$ receptors were present on this cell.

Agonist studies on $I_{\mathrm{Ca}}$ inhibition are summarized in Figure $3 \mathrm{D}$. $I_{\mathrm{Ca}}$ was inlhibited by between 21.8 and $30.2 \%$ by individual agonists; however, there was no significant difference between the four different agonists ( $p>0.30$, Kruskal-Wallis test; Fig. 3D) The effects of NPY ${ }_{13-36}$ were similar in magnitude to the other agonists, although it was effective in only $31 \%$ (5/16 cells) of DGCs that responded to NPY. By contrast, [Leu ${ }^{31} \mathrm{Pro}^{34}$ INPY ( $n$ $=19)$ and PYY $(n=13)$ inhibited the $I_{\mathrm{Ca}}$ in all of the NPYresponsive DGCs on which they were tested.

\section{NPY does not modulate the voltage-dependence of $I_{\text {Ca }}$ activation}

The $I_{\mathrm{Ca}}$ of these small cells often ran down rapidly, making the construction of a current-voltage relationship of the $I_{\mathrm{Ca}}$ from a family of voltage steps under several conditions very difficult. To circumvent this problem, we ramped the voltage of the DGC membrane $\left(V_{\mathrm{m}}\right)$ from -80 to $+70 \mathrm{mV}$ over $100 \mathrm{msec}$ (Fig. 4$)$. The $I_{\mathrm{Ca}}$ of this DGC was inhibited by NPY with no change in the $V_{\mathrm{m}}$ range of $I_{\mathrm{Ca}}$ activation or the $V_{\mathrm{m}}$ where $I_{\mathrm{Ca}}$ reached a maximum (Fig. 4). This DGC was insensitive to $\mathrm{NPY}_{13-36}$ (Fig. 4). NPY ( $n$ $=7)$, $\left[\mathrm{Leu}^{31} \operatorname{Pro}^{34}\right] \mathrm{NPY}(n=4)$, and PYY $(n=3)$ inhibited $I_{\mathrm{Ca}}$ elicited by voltage ramps in other DGCs without shifting the voltage range of activation or the $V_{\mathrm{m}}$ at which $I_{\mathrm{Ca}}$ peaked. We did not see an inhibition of voltage-ranped $I_{\mathrm{Ca}}$ by $\operatorname{NPY}_{13-36}(n=2)$. The $I_{\mathrm{Ca}}$ of one voltage-ramped DGC did not respond to NPY. 


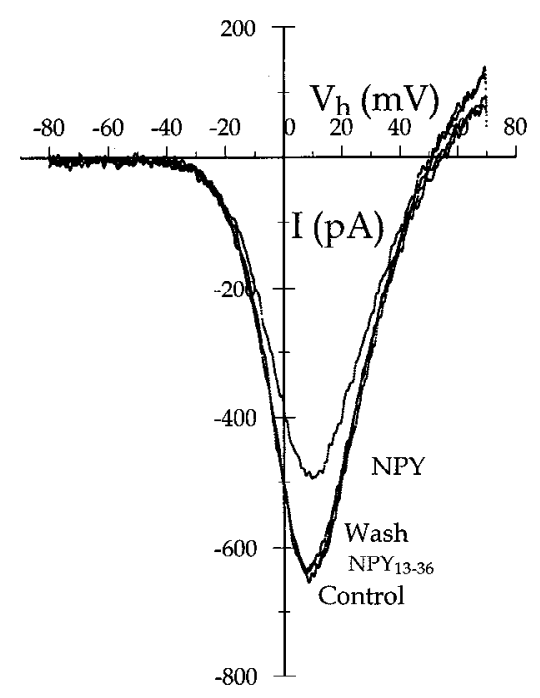

Figure 4. NPY inhibition of $I_{\mathrm{Ca}}$ does not shift the current-voltage relationship of $I_{\mathrm{Ca}} . N P Y$ but not $N P Y_{13-36}$ inhibited $I_{\mathrm{Ca}}$ elicited in a DGC by a $100 \mathrm{msec}$ voltage ramp from -80 to $+70 \mathrm{mV}$. NPY did not shift the voltage range of $I_{\mathrm{Ca}}$ activation or the voltage at which $I_{\mathrm{Ca}}$ reached its maximum.

\section{NPY inhibits an N-type $I_{\text {Ca }}$}

We next sought to determine the type of $I_{\mathrm{Ca}}$ that NPY affected in DGCs. We rarely observed low voltage-activated $I_{\mathrm{Ca}}$ in our DGC preparations and, therefore, we used pharmacological inhibitors of high voltage-activated currents to determine the type or types of $I_{\mathrm{Ca}}$ inhibited by NPY in DGCs. We applied either NPY or $\left[\mathrm{Leu}^{31} \mathrm{Pro}^{34}\right] \mathrm{NPY}$ first in the absence and then in the presence of the L-type $I_{\mathrm{Ca}}$ inhibitor nimodipine $(1-5 \mu \mathrm{M})$ or the N-type $I_{\mathrm{Ca}}$ inhibitor $\omega$-CTX GVIA $(3-5 \mu \mathrm{M})$. The peak $I_{\mathrm{CA}}$ was inhibited by $44 \pm 6 \%(n=9)$ by $\omega$-CTX GVIA and by $23 \pm 6 \%(n=7)$ by nimodipine. The time plot of Figure $5 A$ demonstrates that $\omega$-CTX GVIA completely occluded the $\left[\mathrm{Leu}^{31} \mathrm{Pro}^{34}\right] \mathrm{NPY}$ inhibition of $I_{\mathrm{Ca}}$ in this DGC. The same observation was made in seven other cells inhibitcd by NPY and in onc other cell inhibitcd by $\left[\mathrm{Leu}^{31} \mathrm{Pro}^{34}\right]$ NPY. The data are summarized in Figure 6. Figure $5 B$ illustrates that $\omega$-CTX GVIA completely occludes the inhibition of $I_{\mathrm{Ca}}$ by NPY $(n=7)$. By contrast, nimodipine did not significantly reduce the inhibition of $I_{\mathrm{Ca}}$ by NPY (Fig. $5 B ; n=7$ ).

Two factors complicated this observation. First, we observed that the magnitude of $I_{\mathrm{Ca}}$ suppression by NPY diminishes by $32 \pm$ $10 \%(n=8)$ with the second application of NPY to the same neuron (Fig. 5C). Because we always first tested the effect of NPY alone, the response ran down, resulting in a systematic underestimate of the inhibition of $I_{\mathrm{Ca}}$ by NPY in nimodipine. We therefore corrected the observed value of $I_{\mathrm{Ca}}$ inhibition by NPY in nimodipine for the rundown of the NPY response (Fig. 5D, Corrected). Second, if NPY does not affect L-type VDCCs, then it should inhibit a greater percentage of the $I_{\mathrm{Ca}}$ that remains after nimodipine treatment. We therefore predicted the effect of NPY on the nimodipinc-insensitive $I_{\mathrm{Ca}}$ on the basis of the first effect of NPY and the amount of current inhibited by nimodipine (Fig. $5 D$, Predicted). There was no significant difference between the two (Wilcoxon signed rank test, $p>0.73$ ), suggesting that there is indeed no effect of nimodipine on the $I_{\mathrm{Ca}}$ reduced by NPY receptors in these neurons.

\section{Inhibition of $I_{\mathrm{Ca}}$ by NPY is $\mathrm{Ca}^{2+}$-sensitive}

In experiments on dissociated cells recorded under conditions that favored a moderate resting $\left[\mathrm{Ca}^{2+}\right]_{\mathrm{i}}\left(\mathrm{Ca}^{2+}\right.$ as the charge carrier and minimal buffering of $\left.\left[\mathrm{Ca}^{2+}\right]_{\mathrm{i}}\right), 42$ of $50 \mathrm{DGCs}$ responded to NPY (Fig. 6). By contrast, under experimental conditions favoring low $\left[\mathrm{Ca}^{2+}\right]_{\mathrm{i}}\left(\mathrm{Ba}^{2+}\right.$ as the charge carrier and strong buffering of $\left.\left[\mathrm{Ca}^{2+}\right]_{\mathrm{i}}\right)$, NPY inhibited the $I_{\mathrm{Ca}}$ of only $23 \%$ of DGCs ( $n=121$; Fig. 6). In the same cells, the $I_{\mathrm{Ba}}$ was reversibly inhibited by at least $15 \%$ in 22 of 27 cells tested with the application of 10 $\mu \mathrm{M}$ baclofen (not shown), indicating that another agonist was capable of inhibiting $I_{\mathrm{Ca}}$ in a much greater percentage of these cells under these circumstances.

\section{DISCUSSION}

We report here that NPY inhibits an N-type calcium channel in the soma and dendrites of rat hippocampal DGCs by activating predominantly $Y_{1}$ receptors. This inhibition results in significantly smaller elevations in $\left[\mathrm{Ca}^{2+}\right]_{i}$ during depolarizing electrical activity. To our knowledge, this is the first report of NPY inhibiting an $I_{\mathrm{Ca}}$ in the soma of a central neuron, and the first report of NPY inhibiting an $I_{\mathrm{Ca}}$ by the activation of a $\mathrm{Y}_{1}$ receptor. $\mathrm{Y}_{1}$-receptor activation has until now been associated with the activation or potentiation of different physiological processes (Michel, 1991; Wahlestedt and Reis, 1993; Wiley et al., 1993). Our observations suggest that the role of $Y_{1}$ receptors in the CNS may differ from that in other tissues (Michel, 1991; Wiley et al., 1993; Xiong et al., 1993).

The imaging experiments did not show the elevation in resting $\left[\mathrm{Ca}^{2+}\right]_{i}$ of DGCs with NPY that we had first hypothesized, but instead demonstrated the inhibition of depolarization-induced increases in $\left[\mathrm{Ca}^{2+}\right]_{i}$ in their somata and dendrites. We did not observe a change in the holding current during the application of NPY to intact cells in slices, making it unlikely that NPY activates or potentiates a potassium conductance in these cells (Zidichouski et al., 1990; Illes et al., 1993), in agreement with previous observations (Klapstein and Colmers, 1993). There was also no evidence of a direct excitatory effect (Brooks et al., 1987). The simplest explanation for these observations is that NPY inhibits a VDCC in DGCs, and the experiments on the acutely dissociated DGCs support this conclusion.

In the NPY-responsive DGCs to which selective agonists were applied, $\left[\mathrm{Leu}^{31} \mathrm{Pro}^{34}\right] \mathrm{NPY}$ and PYY always inhibited $I_{\mathrm{Ca}}$. In contrast, $\mathrm{NPY}_{13-36}$ was inactive in a majority of NPY-sensitive DGCs. Because NPY ${ }_{13-36}$ is inactive at $Y_{1}$ receptors, with the highest activity at $Y_{2}$ and less activity at $Y_{3}$ receptors (Michel et al., 1991; Foucart et al., 1993), it can be concluded that in a majority of DGCs $I_{\mathrm{Ca}}$ is inhibited via a $\mathrm{Y}_{1}$ receptor-mediated mechanism. In DGCs that responded to NPY ${ }_{13-36}$, NPY must be activating more than one receptor, but no single agonist used here is entirely selective for any one receptor subtype (Michel, 1991; Dumont et al., 1992). The exact combination of receptors present on these DGCs may involve the combination of any two or perhaps all three receptor subtypes. Because all NPY-sensitive DGCs seem to be responsive to $\left[\mathrm{Leu}^{31} \mathrm{Pro}^{34}\right] \mathrm{NPY}$ and most respond to PYY, we believe that $Y_{1}$ receptors are likely to be present on the cells that also respond to NPY ${ }_{13-36}$. These observations agree with binding studies showing a preponderance of $Y_{1}$-binding sites in rat dentate gyrus, with far fewer $\mathrm{Y}_{2}$ sites (Dumont et al., 1990, 1993; Aicher et al., 1991). The present observations are of potential importance because the majority of the NPY binding in rat cortex is $Y_{1}$ (Dumont et al., 1993).

In most PNS neurons in which it has been studied, $I_{\mathrm{Ca}}$ inhibition by NPY is mediated by a $Y_{2}$ receptor (Bleakman et al., 1991, 1992; Wiley et al., 1993), although in one case, $Y_{3}$ receptors also seemed to inhibit $I_{\mathrm{Ca}}$ (Foucart et al., 1993). $\mathrm{Y}_{1}$-receptor activation, by 


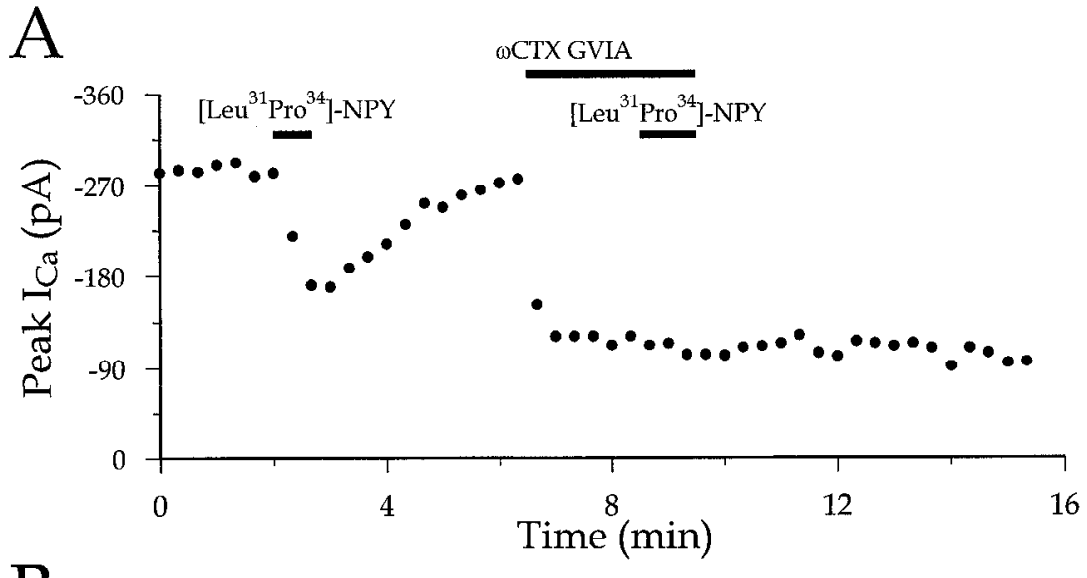

$\mathrm{B}$
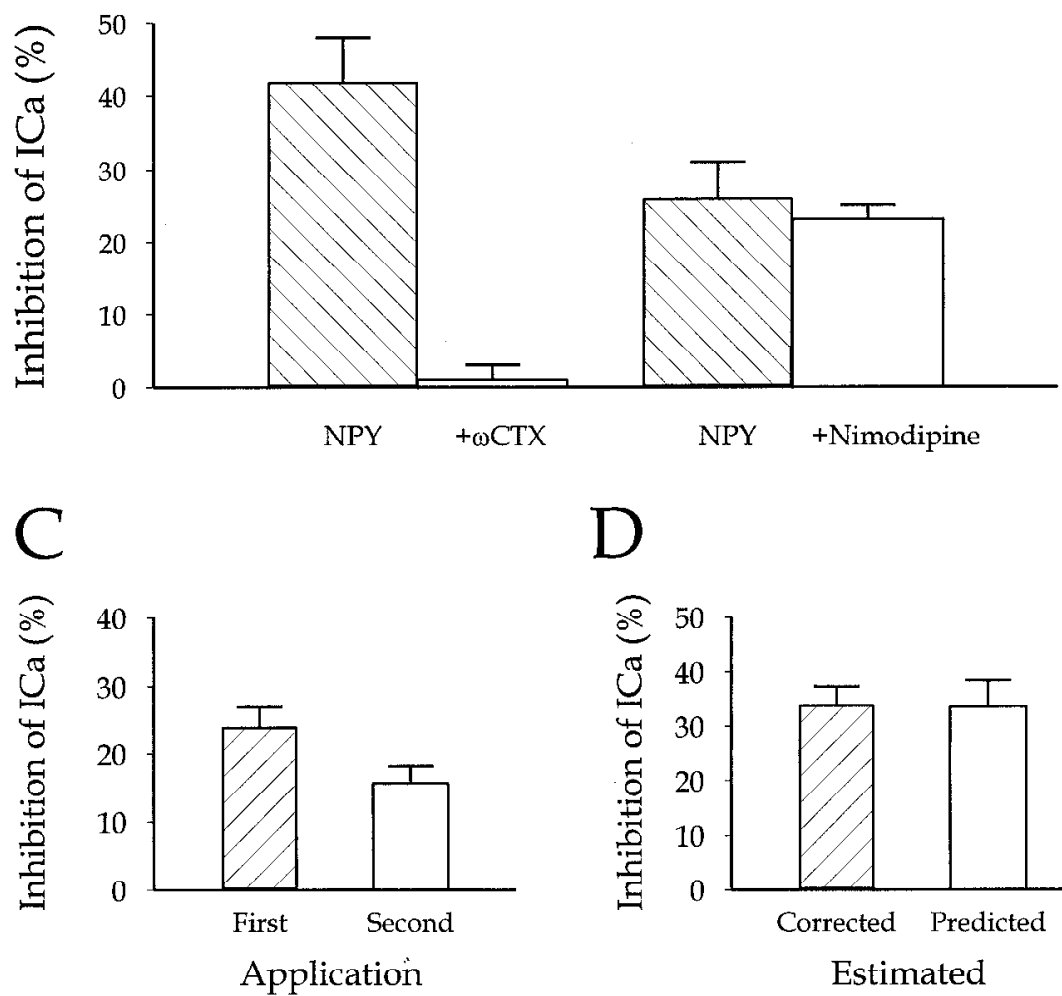

contrast, usually results in a potentiating effect on $I_{\mathrm{Ca}}$. For example, in rat nodose ganglia, $\mathrm{Y}_{1}$-receptor activation potentiates the same $I_{\mathrm{Ca}}$ that is reduced by $\mathrm{Y}_{2}$-receptor activation (Wiley et al., 1993). $Y_{1}$-receptor activation potentiates $\alpha_{1}$-adrenoceptor actions in vascular smooth muscle (Zukowska-Grojec and Wahlestedt, 1993) and potentiates L-type VDCCs in vascular smooth muscle (Xiong et al., 1993). Such $Y_{1}$-mediated potentiations in $I_{\mathrm{Ca}}$ contrast with the observed $Y_{1}$-receptor action in the rat DGCs.

Our data demonstrate that NPY inhibits an N-type $I_{\mathrm{Ca}}$ in rat DGCs. In every case, the NPY- or $\left[\mathrm{Leu}^{31} \mathrm{Pro}^{34}\right] \mathrm{NPY}$-mediated inhibition of $I_{\mathrm{Ca}}$ was entirely occluded by $\omega$-CTX GVIA but not by nimodipine. The amount of $I_{\mathrm{Ca}}$ inhibited by NPY in the presence of nimodipine, when corrected for the rundown of the response, matches the predicted magnitude of inhibition of $I_{\mathrm{Ca}}$ if NPY were to have no effect on nimodipine-sensitive VDCCs. NPY inhibits an $\mathrm{N}$-type current in numerous other cell types (for review, see Bleakman et al., 1993; Colmers and Bleakman, 1994). As an aside, it is interesting to note that $\omega$-CTX GVIA inhibited only $20 \%$ of
Figure 5. NPY inhibits an N-type $I_{\mathrm{Ca}}$ in acutely dissociated DGCs. $A$, Details of the experiment are as in Figure 3. The $\mathrm{Y}_{1}$ agonist $\left[\mathrm{Leu}^{31} \mathrm{PrO}^{34}\right]-N P Y$ inhibited $I_{\mathrm{Ca}}$ by $44 \%$. Application of $5 \mu \mathrm{M} \omega C T X$ GVIA reduced $I_{\mathrm{Ca}}$ by $60 \%$ and entirely occluded the response to the subsequent application of NPY. Similar results were obtained for NPY in seven additional cells and in one other cell for [ $\mathrm{Leu}^{31}$ Pro $\left.^{34}\right]$ NPY. $B$, Inhibition of $I_{\mathrm{Ca}}$ by $N P Y$ in seven neurons (left bars; $42 \pm 6 \%$ ) is completely occluded by $3-5 \mu \mathrm{M} \omega$-CTX GVIA $(+\omega C T X ; 1 \pm 2 \%, p<0.02$ Wilcoxon signed rank test). Inhibition of $I_{\mathrm{Ca}}$ by $N P Y$ (right bars, $26 \pm 5 \%$ ) is not affected by treatment with 3 $\mu \mathrm{M}$ nimodipine (+Nimodipine, $23 \pm 6 \%, n=7, p>0.59$, Wilcoxon signed rank test). $C$, The inhibition of $I_{\mathrm{Ca}}$ produced in eight different cells by a second application of NPY (open bar, $16 \pm 3 \%$ ) is reduced by $32 \pm 10 \%$ compared with the inhibition produced by the first application of NPY (hatched bar, $24 \pm 3 \%, n=8, p<0.02$, Wilcoxon signed rank test). $D$, Estimated inhibition of $I_{\mathrm{Ca}}$ by NPY. The value of $I_{\mathrm{Ca}}$ inhibition in nimodipine corrected for the rundown of the NPY response (34 \pm $3 \%$; Corrected, hatched bar), compared with the value of $I_{\mathrm{Ca}}$ inhibition predicted from the nimodipine-sensitive $I_{\mathrm{Ca}}(34 \pm 5 \%$; Predicted, open bar). These two values do not differ statistically $(p>0.39$, Wilcoxon signed rank test). the $I_{\mathrm{Ca}}$ in DGCs isolated from the guinea pig hippocampus (Eliot and Johnston, 1994) compared with the 44\% inhibition reported here in the rat, suggesting a substantial species difference in these cells.

In the majority of DGCs studied, NPY inhibited $I_{\mathrm{Ca}}$ without changing the time course of $I_{\mathrm{Ca}}$. In $\sim 25 \%$ of DGCs, however, NPY inhibition of $I_{\mathrm{Ca}}$ was accompanied by a slowing of the time course of activation, as has been seen elsewhere (Bean, 1989; Hille, 1994). Here, NPY did not change the voltage range at which $I_{\mathrm{Ca}}$ activated or the $V_{\mathrm{m}}$ at which $I_{\mathrm{Ca}}$ reached a maximum. Previous investigations in other types of neurons have demonstrated that other neuromodulators can inhibit $I_{\mathrm{Ca}}$ by two distinct mechanisms, as NPY seems to do in DGCs (Beech et al., 1992; Formenti et al., 1993; Toselli and Taglietti, 1993; Luebke and Dunlap, 1994). Most of the DGCs here responded to NPY without an apparent alteration in the time course of their $I_{C a}$ as nthers have observed in a proportion of chick sensory neurons (Luebke and Dunlap, 1994). Because of the relative rarity of the altered time 


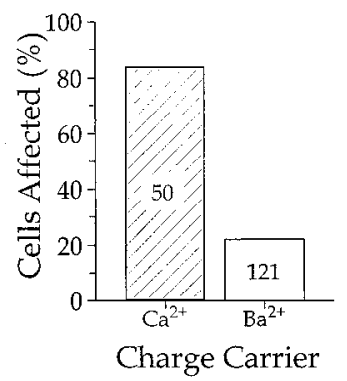

Figure 6. NPY Inhibition of $I_{\mathrm{Ca}}$ in acutely dissociated DGCs is sensitive to calcium. The left bar $\left(\mathrm{Ca}^{2+}\right)$ indicates the percentage of NPY-responsive cells recorded with $5 \mathrm{mM} \mathrm{Ca}^{2+}$ in the extracellular solution as the charge carrier and low $\left(0.1 \mathrm{~mm}\right.$ BAPTA) intracellular $\mathrm{Ca}^{2+}$ buffering. The right bar $\left(\mathrm{Ba}^{2+}\right)$ indicates the percentage of NPY-responsive cells recorded with $5 \mathrm{mM} \mathrm{Ba}^{2+}$ in the extracellular solution as the charge carrier and high $(20 \mathrm{mM}$ BAPTA with no added $\mathrm{Ca}^{2+}$ ) intracellular $\mathrm{Ca}^{2+}$ buffering. Numbers within bars indicate the number of observations.

course, we did not perform the depolarizing prepulse experiments necessary to distinguish between the two mechanisms (Luebke and Dunlap, 1994). Additional studies are needed to elucidate the pathways by which the receptor couples to the calcium channels.

Inhibition of $I_{\mathrm{Ca}}$ in rat DGCs by NPY also seems to be sensitive to $\left[\mathrm{Ca}^{2+}\right]_{\mathrm{i}}$. Recording conditions favoring low $\left[\mathrm{Ca}^{2+}\right]_{\mathrm{i}}$ (i.e., high intracellular $\mathrm{B} \Lambda \mathrm{PT} \Lambda$ concentrations) greatly reduce the proportion of cells responding to NPY. Only $23 \%$ of DGCs responded to NPY when $\mathrm{Ba}^{2+}$ was the charge carrier and internal $\mathrm{Ca}^{2+}$ was strongly buffered. However, baclofen reversibly inhibited $I_{\mathrm{Ba}}$ in $81 \%$ of DGCs tested under the same conditions. When recording conditions were changed to favor higher $\left[\mathrm{Ca}^{2+}\right]_{i}$, (i.e., low intracellular BAPTA concentrations), the proportion of DGCs responding to NPY increased to $84 \%$. Recent studies have shown that inhibition of $I_{\mathrm{Ca}}$ in neurons is caused by a number of distinct mechanisms (for review, see Hille, 1994). One such mechanism is sensitive to $\left[\mathrm{Ca}^{2+}\right]_{\mathrm{i}}$. Buffering $\left[\mathrm{Ca}^{2+}\right]_{\mathrm{i}}$ to very low concentrations either blocks or reduces the inhibition of $I_{\mathrm{Ca}}$ by metabotropic glutamate receptors in cultured hippocampal neurons (Lester and Jahr, 1990) and by $\mathrm{M}_{1}$ acetylcholine and angiotensin II receptors in rat superior cervical ganglion neurons (SCG) (Beech et al., 1991; Shapiro et al., 1994). The mechanism of this $\mathrm{Ca}^{2+}$ and BAPTA sensitivity is unknown; however, in rat SCG neurons the $\mathrm{Ca}^{2+}$ sensitivity does not involve intracellular stores of $\mathrm{Ca}^{2+}$ (Beech et al., 1991). More recently, it has been shown in chick sensory neurons that $\alpha_{2}$ adrenoceptors can activate two pathways that inhibit $\mathrm{N}$-type $I_{\mathrm{Ca}}$, one of which does not alter the time course of current activation and which involves protein kinase $\mathrm{C}$ (Diversé-Pierliussi et al., 1995). The DGCs here that responded to NPY with a change in $I_{\mathrm{Ca}}$ activation kinetics had a larger inhibitory response to NPY. One potential interpretation of this observation is that all DGCs responding to NPY possess the pathway that does not alter the activation kinetics, whereas some have, in addition, the pathway that alters the kinetics of $I_{\mathrm{Ca}}$ activation.

Although NPY inhibits an N-type VDCC in rat DGCs via the activation of $Y_{1}$ receptors, the biological purpose of this action is not clear. NPY has no evident effect on the synaptic inputs or excitability of DGCs (Klapstein and Colmers, 1993). The DGCs, however, release not only glutamate but also peptides, particularly dynorphin, which they can release from their dendrites as well as from their terminals (Drake et al., 1994). The release of dynorphin from the dendrites of DGCs depends on L- and N-type channels (Simmons et al., 1995). It is tempting to speculate that the release of NPY in the dentate gyrus will inhibit the release of dynorphin and possibly other peptides (Morris et al., 1988; Goodman and Sloviter, 1993) from DGCs. This would tend to reduce the influence of opioid peptides when levels of activity in the dentate gyrus were high.

Alternatively, or in addition, the regulation of $\mathrm{Ca}^{2+}$ influx by NPY could affect the expression of immediate early genes (Morgan and Curran, 1986; Murphy et al., 1991; Ghosh et al., 1994) and/or could act to prevent damaging levels of $\mathrm{Ca}^{2+}$ influx under conditions of elevated levels of excitation.

\section{REFERENCES}

Aicher SA, Springton M, Berger SB, Reis DJ, Wahlestedt C (1991) Receptor-selective analogs demonstrate NPY/PYY receptor heterogeneity in rat brain. Neurosci Lett 130:32 36.

Bean BP (1989) Neurotransmitter inhibition of neuronal calcium currents by changes in channel voltage dependence. Nature 340:153-156.

Beech DJ, Bernheim L, Mathie A, Hille B (1991) Intracellular $\mathrm{Ca}^{2+}$ buffers disrupt muscarinic suppression of $\mathrm{Ca}^{2+}$ current and $\mathrm{M}$ current in rat sympathetic neurons. Proc Natl Acad Sci USA 88:652-656.

Beech DJ, Bernheim L, Hille B (1992) Pertussis toxin and voltage dependence distinguish multiple pathways modulating calcium channels in rat sympathetic neurons. Neuron 8:97-106.

Blanton MG, Lo Turco JJ, Kriegstein AR (1989) Whole cell recording from neurons in slices of reptilian and mammalian cerebral cortex. $J$ Neurnsci Methods 30:203-210.

Bleakman D, Colmers WF, Fournier A, Miller RJ (1991) Neuropeptide $\mathrm{Y}$ inhibits $\mathrm{Ca}^{2+}$ influx into cultured dorsal root ganglion neurones of the rat via a $Y_{2}$ receptor. Br J Pharmacol 103:1781 1789.

Bleakman D, Harrison NL, Colmers WF, Miller RJ (1992) Investigations into neuropeptide Y-mediated presynaptic inhibition in cultured hippocampal neurones of the rat. Br J Pharmacol 107:334-340.

Bleakman D, Miller RJ, Colmers WF (1993) Actions of neuropeptide Y on the electrophysiological properties of nerve cells. In: The biology of neuropeptide $Y$ and related peptides (Colmers WF, Wahlestedt C, eds), pp 241-272. Totowa, NJ: Humana.

Brooks PA, Kelly JS, Allen JM, Smith DAS, Stone TW (1987) Direct excitatory effects of neuropeptide Y (NPY) in rat hippocampal neurones in vitro. Brain Res 408:295-298.

Colmers WF, Bleakman D (1994) Fffects of neuropeptide $Y$ on the electrical properties of neurons. Trends Neurosci 17:373-379.

Colmers WF, Lukowiak K, Pittman QJ (1987) Presynaptic action of neuropeptide $\mathrm{Y}$ in area $\mathrm{C} \Lambda 1$ of the rat hippocampal slice. J Physiol (Lond) 383:285-299.

Colmers WF, Lukowiak K, Pittman QJ (1988) Neuropeptide Y action in the rat hippocampal slice: site and mechanism of presynaptic inhibition. J Neurosci 8:3827-3837.

Connor JA (1986) Digital imaging of free calcium changes and of spatial gradients in growing processes in single, mammalian central nervous system cells. Proc Natl Acad Sci USA 83:6179-6183.

Diversé-Pierluissi M, Goldsmith PK, Dunlap K (1995) Transmittermediated inhibition of N-type calcium channels in sensory neurons involves multiple GTP binding proteins and subunits. Neuron $14: 191-200$.

Drake CT, Terman GW, Simmons ML, Milner TA, Kunkel DD, Schwartzkroin PA, Chavkin C (1994) Dynorphin opioids present in dentate granule cells may function as retrograde inhibitory transmitters. J Neu rosci 14:3736-3750.

Dumont Y, Fournier A, St-Pierre S, Schwartz TW, Quirion R (1990) Differential distribution of neuropeptide $Y_{1}$ and $Y_{2}$ receptors in the ral brain. Eur J Pharmacol 191:501-503.

Dumont Y, Martel J-C, Fournier A, St-Pierre S, Quirion R (1992) Neuropeptide $\mathrm{Y}$ and neuropeptide $\mathrm{Y}$ receptor subtypes in brain and peripheral tissues. Prog Neurobiol 38:125-167.

Dumont Y, Fournier A, St-Pierre S, Quirion R (1993) Comparative characterization and autoradiographic distribution of neuropeptide $Y$ receptor subtypes in the rat brain. J Neurosci 13:73-86.

Eliot LS, Johnston D (1994) Multiple components of calcium current in acutely dissociated dentate gyrus granule neurons. J Neurophysiol $72: 762-777$.

Formenti $\Lambda$, Arrigoni E, Mancia M (1993) Two distinct modulatory effects on calcium channels in adult rat sensory neurons. Biophys $\mathrm{J}$ 64:1029-1037. 
Foucart S, Bleakman D, Bindokas VP, Miller RJ (1993) Neuropeptide Y and pancreatic polypeptide reduce calcium currents in acutely dissociated neurons from adult rat superior cervical ganglia. J Pharmacol Exp Ther 265:903-909.

Ghosh A, Ginty DD, Bading H, Greenberg ME (1994) Calcium regulation of gene expression in neuronal cells. J Neurobiol 25:294-303.

Goodman JH, Sloviter RS (1993) Cocaine neurotoxicity and altered neuropeptide $\mathrm{Y}$ immunoreactivity in the rat hippocampus: a silver degeneration and immunocytochemical study. Brain Res 616:263-272.

Grundemar L, Sheikh SP, Wahlestedt C (1993) Characterization of receptor types for neuropeptide $Y$ and related peptides. In: The biology of neuropeptide $\mathrm{Y}$ and related peptides (Colmers WF, Wahlestedt C, eds), pp 197-239. Totowa, NJ: Humana.

Grynkiewicz G, Poenie M, Tsien RY (1985) A new generation of $\mathrm{Ca}^{2+}$ indicators with greatly improved fluorescence properties. J Biol Chem $260: 3440-3450$.

Haas HL, Hermann A, Greene RW, Chan-Palay V (1987) Action and location of neuropeptide tyrosine (Y) on hippocampal neurons of the rat in slice preparations. J Comp Neurol 257:208-215.

Hamill OP, Marty A, Neher E, Sakmann B, Sigworth FJ (1981) Improved patch-clamp techniques for high-resolution current recording from cells and cell-free membrane patches. Pflügers Arch 391:85-100.

Hendry SHC (1993) Organization of neuropeptide $Y$ neurons in the mammalian central nervous system. In: The biology of neuropeptide $Y$ and related peptides (Colmers WF, Wahlestedt C, eds), pp 65-156. Totowa, NJ: Humana.

Hille B (1994) Modulation of ion-channel function by G-protein-coupled receptors. Trends Neurosci 17:531-536.

Hjorth-Simonsen A, Jeune B (1972) Origin and termination of the hippocampal perforant path in the rat studied by silver impregnation. $J$ Comp Neurol 144:215-232.

liles P, Finta EP, Nieber K (1993) Neuropeptide $Y$ potentiates via $Y_{2}$ receptors - the inhibitory effect of noradrenaline in rat locus coeruleus neurones. Naunyn Schmiedebergs Arch Pharmacol 348:546-548.

Kay AR (1989) A procedure for isolating neurons from the mature mammalian brain. In: A dissection and tissue culture manual of the nervous system (Shahar A, de Vellis J, Vernadakis A, Haber B, eds), pp 54-59. New York: Liss.

Klapstein GJ, Colmers WF (1993) On the sites of presynaptic inhibition by neuropeptide $\mathrm{Y}$ in rat hippocampus in vitro. Hippocampus 3:103-112.

Laatch RH, Cowan WM (1967) Electron microscopic studies of the dentate gyrus of the rat. II. Degeneration of commissural afferents. J Comp Neurol 130:241-262.

Lester RAJ, Jahr CE (1990) Quisqualate receptor-mediated depression of calcium currents in hippocampal neurons. Neuron 4:741-749.

Luebke JI, Dunlap K (1994) Sensory neuron N-type calcium currents are inhibited by both voltage-dependent and -independent mechanisms. Pflügers Arch 428:499-507.

McQuiston AR, Colmers WF (1992) Neuropeptide Y does not alter NMDA conductances in CA3 pyramidal neurons: a slice-patch study. Neurosci Lett 138:261-264.
Michel MC (1991) Receptors for neuropeptide Y: multiple subtypes and multiple second messengers. Trends Pharmacol 12:389-394.

Mody I, Salter MW, MacDonald JF (1989) Whole cell voltage-clamp recordings in granule cells acutely isolated from hippocampal slices of adult or aged rats. Neurosci Lett 96:70-75.

Morgan JI, Curran T (1986) Role of ion influx in the control of c-fos expression. Nature 322:552-555.

Morris BJ, Feasy KJ, Ten Bruggecate G, Herz A, Höllt V (1988) Electrical stimulation in vivo increases the expression of procnkephalin mRNA and decreases the expression of prodynporphin mRNA in rat hippocampal granule cells. Proc Natl Acad Sci USA 85:3226-3230.

Murphy TH, Worely PF, Baraban JM (1991) L-type voltage-sensitive calcium channels mediate synaptic activation of immediate early genes. Neuron 7:625-635.

Shapiro MS, Wollmuth LP, Hille B (1994) Angiotensin II inhibits calcium and $\mathrm{M}$ current channels in rat sympathetic neurons via $\mathrm{G}$ proteins. Neuron 12:1319-1329.

Simmons ML, Terman GW, Gibbs SM, Chavkin C (1995) L-type calcium channels mediate dynorphin neuropeptide release from dendrites but not axons of hippocampal granule cells. Neuron 14:1265-1272.

Sundler F, Bottcher G, Ekblad E, Hakanson R (1993) PP, PYY, and NPY: occurrence and distribution in the periphery. In: The biology of neuropeptide $\mathrm{Y}$ and related peptides (Colmers WF, Wahlestedt C, eds), pp 157-196. Totowa, NJ: Humana.

Toselli M, Taglietti V (1993) Baclofen inhibits high-threshold calcium currents with two distinct modes in rat hippocampal neurons. Neurosci Lett 164:134-136.

Tsien RY (1989) Fluorescent indicators of ion concentrations. Methods Cell Biol 30:127-156.

Valentijn JA, Vaudry H, Kloas W, Cazin L (1994) Melanostatin (NPY) inhibited electrical activity in frog melanotrophs through modulation of $\mathrm{K}^{+}, \mathrm{Na}^{+}$and $\mathrm{Ca}^{2+}$ currents. J Physiol (Lond) 475:185-195.

Wahlestedt C, Reis DJ (1993) Neuropeptide Y-related peptides and their receptors-are the receptors potential therapeutic drug targets? Annu Rev Pharmacol Toxicol 33:309-352.

White JA, Alonso A, Kay AR (1993) A heari-like $\mathrm{Na}^{+}$current in the medial entorhinal cortex. Neuron 11:1037-1047.

Wiley JW, Gross RA, MacDonald RL (1993) Agonists for neuropeptide Y receptor subtypes NPY-1 and NPY-2 have opposite actions on rat nodose calcium currents. J Neurophysiol 70:324-330.

Xiong 7, Bolzon B.T, Cheung DW (1993) Neuropeptide Y potentiates calcium-channel currents in single vascular smooth muscle cells. Pflügers Arch 423:504-510.

Zidichouski JA, Chen II, Smith PA (1990) Neuropeptide Y activates inwardly rectifying $\mathrm{K}^{+}$-channels in C-cells of amphibian sympathetic ganglia. Neurosci Lett 117:123-128.

Zukowska-Grojec Z, Wahlestedt C (1993) Origin and actions of neuropeptide $\mathrm{Y}$ in the cardiovascular system. In: The biology of neuropeptide $\mathrm{Y}$ and related peptides (Colmers WF, Wahlestedt $\mathrm{C}$, eds), pp 315-388. Totowa, NJ: Humana. 